\title{
Specific Target Organ Toxicity (STOT) After Acute Exposure of Dinotefuan And Its Attenuation With Vitamin C Supplementation
}

Hafiz Muhammad Ahmad

University of Veterinary and Animal Sciences

Munazza Raza Mirza

Dr Panjwani Center for Molecular Medicine and Drug Research

Muhammad Shahbaz Yousaf

University of Veterinary and Animal Sciences

Sehrish firyal

University of Veterinary and Animal Sciences

Muhammad Muddassir Ali

University of Veterinary and Animal Sciences

Rahat Naseer ( $\nabla$ rahat.naseer@uvas.edu.pk)

University of Veterinary and Animal Sciences https://orcid.org/0000-0002-8618-2495

\section{Research Article}

Keywords: Dinotefuran, Vitamin C, Tissue Specific Toxicity, Acute Exposure

Posted Date: August 10th, 2021

DOl: https://doi.org/10.21203/rs.3.rs-774618/v1

License: (9) (i) This work is licensed under a Creative Commons Attribution 4.0 International License. Read Full License 


\section{Abstract}

The present study was designed to evaluate the effect of 2-methyl-2-nitro-3-guanidine on non-target mammalian species after acute exposure and its probable. Forty-five four weeks old Sprague Dawley rats of mixed sexes having mean body weight $(80 \pm 20 \mathrm{~g})$ were randomly divided into three groups fifteen each, namely C (control), E(exposed), and V (exposed and vitamin supplemented) group. The $\mathrm{E}$ and $\mathrm{V}$ groups were exposed to $2000 \mathrm{mg} / \mathrm{kg}$ of body weight via gauge. The vitamin C was administrated by dissolving $400 \mathrm{mg} / 350 \mathrm{ml}$ of water and given ad libitum (LD50). Eight hours after dosing $5 \mathrm{ml}$ blood was collected by cardiac puncture under sedation. After 48 hours five rats were selected randomly from each group, anesthetized, euthanized, and dissected. Mortalities in each group were taken into account to reduce decretory mortality. Different body tissues, liver, kidney, heart, and bones were separated and preserved in formalin for further analysis. Complete blood count was conducted along with markers of liver kidney and heart function. Bone characteristics and histopathology of soft tissues were carried out. Results showed significant disturbance in $\mathrm{CBC}$ and other biomarkers of liver kidney and heart function in the E group. Vitamin supplementation although improved the picture but non-significantly.

Histopathology showed signs of necrosis in the exposed group with no improvement in the $\mathrm{C}$ group. The weight/Length index and the robusticity index were also found to follow similar trends. The present study was cautiously concluded that even single high dose exposure can cause tissue damage in non-target species.

\section{Introduction}

Neonicotinoids in the class of neurotoxic insecticides which are highly systemic have a very unique mode of action and broad-spectrum efficacy. They irreversibly bind with the nicotinic receptors of acetylcholine, blocking the nerve impulses in insects. On the contrary, they are claimed to be less toxic towards mammals, fishes, and birds (Tomizawa and Casida 2005). Although many nicotinoids like imidacloprid and clothianidin show very strong toxicity towards pollinating insects, particularly to honey bees (Apis mellifera L.) there market share showed a steady rise and it is $24 \%$ of total insecticides turnover (Jeschke et al. 2010).

Before being registered, the formulated pesticides are currently undergoing various tests to evaluate the risk that these molecules pose to honey bees. In the European Union, the guidelines of the European and Mediterranean Plant Protection Organization No. 170 (OEPP / EPPO, 2001) and the relative riskassessment procedure are generally followed, but their efficiency for systemic insecticide has recently been questioned, with particular reference to neonicotinoids (Halm et al. 2006).

The dinotefuran [1-methyl-2-nitro-3-(tetrahydro-3-furyl methyl) guanidine], is the most advanced neonicotinoid insecticide and is widely used for crop protection due to its less toxic effect on human health. It is utilized as a high potential insecticide to control various sucking and plant bugs like insects like beetles, whiteflies, green rice leafhoppers, and aphids due to its capability to block the nicotinic 
acetylcholine receptors unlike the other insecticides (Bass et al. 2011) ; (Hem et al. 2012). Presently, it has been popularized and connected in various strategies throughout the planet (Rahman et al. 2015).

It demonstrates brilliant properties i.e. rapid take-up and translocation in plants, high insecticidal action, safe for the atmosphere and people(Watanabe et al. 2011), steady towards soil condition, and a half-life of 50-100 days (Morrissey et al. 2015). Even though neonicotinoid insecticides are expected to have destructive and harmful effects on animals, there is minimal animal experimental information available to understand their impact and mechanism of action (Yoneda et al. 2018). The present study is designed to assess the systemic effect of acute exposure of dinotefuran on different mammalian tissues.

\section{Materials And Methods}

\subsection{Chemicals and Reagents:}

Dinotefuran [1-methyl-2-nitro-3-(tetrahydro-3-furyl methyl) guanidine] supplied by four brothers, Vitamin C(Merck), Formalin Buffer (Reidel-de Haen) Ethanol (VWR), distill Water, Diethyl Ether (Merck Germany)

\subsection{Methodology:}

Fifteen Sprague Dawley rats of mixed sexes having weight about $80 \pm 20 \mathrm{~g}$ and aged $4 \pm 0.5$ weeks were safely housed as by EU guidelines of animal research at the animal housing facility center of UVAS, Lahore. They were safely kept in stainless steel cages at ambient temperature $\left(21 \pm 2^{\circ} \mathrm{C}\right)$ and $50 \%$ humidity providing basic diet and water ad libitum for about 12 hours to adjust them and afterward were randomly divided into 3 different groups i.e. 5 rats in each group. Group $C$ was our control group, Group $E$ was the pesticide exposure group, and Group $\vee$ was exposed to pesticide and supplemented with vitamin C. Group C and V were gauged $2000 \mathrm{mg} / \mathrm{kg}$ of body weight. Group V was also supplemented provided with Vitamin C (4ml of Vit C dissolved in $350 \mathrm{ml}$ of water).

After 12 hours, $5 \mathrm{ml}$ of blood was collected directly from the heart puncture of each rat. Serum was extracted from $3.5 \mathrm{ml}$ of blood and the remaining $1.5 \mathrm{ml}$ of blood was collected in EDTA vials.

After 48 hours, no mortality was recorded, but among all the groups, four rats were showing the symptoms of lethargy and disinterest in food. All rats were given anesthesia and then slaughtered for organ extraction. The organs under study (liver, kidney, heart, and bone) were preserved in formalin buffer until used for further analysis (Cui et al. 2009). All the procedures were carried out humanly as by the institutional code of animal research.

Histopathology of liver, kidney, and heart was performed according to the procedure of (Cui et al. 2009). The removed left tibia was cleaned and incubated in boiling water for 10 minutes by following the method proposed by (KOCABAĞLI 2001).

The bone weight / length index and robusticity index were determined by the following formulae: 
Weight / Length Index $(\mathrm{mg} / \mathrm{mm})=$ Weight $(\mathrm{mg}) /$ Length $(\mathrm{mm})$ (Seedor et al. 1991)

Robusticity Index $\left(\mathrm{mm} / \mathrm{mg}^{1 / 3}\right)=$ Bone Length $(\mathrm{mm}) /$ Cube root of bone weight $(\mathrm{mg})$ (KOCABAĞLI 2001)

All the observations were collected in triplicate. Thus, the obtained data were statistically analyzed through analysis of variance (ANOVA) and the values were calculated by using SPSS software. The significant difference of each parameter was statistically measured by using a significance level of $a=$ 0.05 .

\section{Results And Discussion}

No mortality and no weight loss were recorded after 48 hours of exposure. Similar results were reported while using other Neonicotinoids like Imidacloprid (10 and $20 \mathrm{mg} / \mathrm{kg} / 60$ days) (Vohra et al. 2014) alone and in combination with Fipronil. Although these studies reported chronic low dose exposure. dose chronic as reported by (Chakroun et al. 2017).

\subsection{Blood Toxicity:}

Complete Blood Count (CBC) of all the fifteen rats which were sampled after 12 hours was carried out. The results of each parameter were pooled to assess the overall blood picture. The mean values of WBCs, MID cells (infrequently existing rare cells having a connection with monocytes, basophils, eosinophils), and granulocytes (GRA) were found to decrease significantly $(p \otimes 0.05)$ while significant Lymphocytosis (LYM) was found ( $p \otimes 0.05$ ) in the experimental group concerning control group. Results also showed a significantly positive effect of vitamin $\mathrm{C}$ supplementation as shown in table no. 1.

This reduction in leukocytes and their types may be attributed to the production of an oxidatively stressed environment resulting in the lysis of the individual cells resulting in depressed hematopoiesis (Chatterjee et al. 2014). However, a transitory rise in lymphocyte count may be due to body defense (BassiniCameron et al. 2007) (Ghazi et al. 2012). As it was an acute trial, so only short-term data is available and shared (Moid et al. 2014). A significant reduction in the number of leukocytes and its various types, except lymphocytes, and significant promotion in the number of lymphocytes (lymphocytosis) in adult Sprague Dawley rats (weighing about 200g) were reported by (Nair et al. 2010) in a study of sublethal toxicity of orally applied cypermethrin.

Table no. 2 explains that mean $( \pm S D$ ) values of RBCs, HGB, HCT, and RDWc were decreased in the experimental group as compared to the control group. On the other hand, mean $( \pm S D)$ values of MCV, $\mathrm{MCH}$, and $\mathrm{MCHC}$ were increased in the intoxicated rat group as compared to the control group. The presence of Vitamin $C$ has reduced the toxicity effect of dinotefuran on RBCs and its related parameters. Several factors have been reported for this reduction in erythrocyte count and hemoglobin concentration like internal hemorrhage (Enan and EE 1983) or depletion in the synthesis of hemoglobin or due to an elevation in the destruction of hemoglobin (Karmakar et al. 2000) (Lal et al. 2011) (Chatterjee et al. 2014). Blood cells affected by toxic substances like insecticides may be responsible for hemolysis (Kataria et al. 
2016). Reduced level of GSH and elevation of lipid peroxidation can cause cell lysis. Similar results were well reported with cypermethrin (Kataria et al. 2016) and imidacloprid (Jasper et al. 2012).

Table no. 3 shows that mean ( \pm SD) values of PLT and PCT \% were decreased in the intoxicated rat group as compared to the control group. But mean ( \pm SD) values of MPV, PDWc, and PLCR \% were increased in the experimental group as compared to the control group. In this case, Vitamin $\mathrm{C}$ also showed its antioxidant and inhibitory effect against the toxic effect of dinotefuran.

Bone marrow is highly responsive to toxic substances like insecticides that are responsible for aplasia, dysplasia, and impairment in cell function (Subramanian 2019). This decrease in platelet number may be due to the impact of insecticide on bone marrow cells either at their synthesis level or their developmental level, resultantly hematopoiesis becomes slow or stops (Chatterjee et al. 2014). A raised mean platelet volume (MPV) level indicates high blood clotting ability. As a result of which there will be more chances of thrombosis, stroke, or cardiovascular disorders (Moid et al. 2014).

Previous results also revealed that sub-acute (28 days) toxicity of diazinon $(20 \mathrm{mg} / \mathrm{kg} / \mathrm{day})$ and imidacloprid in male BALB/c mice and orally administrated female mice for 24 hours was responsible for depletion in platelet number (Zeinali et al. 2018). In another study, when different concentrations of imidacloprid (25\% 50\%, and 75\% of LD50) (Kataria et al. 2016) and (Moid et al. 2014).

\subsection{Liver Toxicity:}

After 48 hours of the trial period, liver histopathology and LFT (Liver Function Test) were performed to evaluate the liver-related disorders and extent of liver damage. Table no. 4 explains the mean $( \pm S D)$ values of hepatic-related serum parameters like alkaline phosphatase (ALP), alanine transaminase (ALT), aspartate transaminase (AST), and bilirubin total. These values were found significantly increased in the experimental group as compared to the control group. Vitamin C showed a significant (antioxidant) effect on mean values of hepatic-related serum parameters.

The elevated level of these enzymes may be due to the interruption of insecticide in the biosynthesis of these enzymes along with the changes in the permeability of hepatic cells by degeneration in hepatic tissues. As a result of which normal or regular functions of the hepatic plasma membrane (especially transportation) are interrupted. Therefore, these enzymes transport from the cytosol of hepatic tissues into the bloodstream (Celik and Suzek 2008) (Jadon et al. 2007). The increased enzymatic activities of ALP, ALT, and AST may also be due to loss of hepatic membrane and hepatocellular damage (Chakroun et al. 2016). Increased levels of ALP, ALT, and AST also indicate tissue damage, necrosis of hepatic tissues (Sathiavelu et al. 2009).

It has already been well documented that the prolonged effect of chlorpyrifos (an organophosphate insecticide), caused (Uzun and Kalender 2013). Imidacloprid (10 and 20 mg/kg/ 60 days) (Vohra et al. 2014) and fipronil are significantly related to increased concentration of liver enzymes although acute exposure requires more study. In both cases, the effect is dose-dependent. 
Hepatic tissue extracted from the control group showed normal cytoplasm with no pyknotic nuclei. There were no morphological changes due to hydropic degeneration, cellular swelling, and any necrosis. There was no congestion in sinusoidal capillaries. On the other hand, there was severe hydropic degeneration and coagulative necrosis in the hepatic tissue of the Experiment group (LD50). Severe hydropic degeneration was also seen in the hepatic tissue of the Vitamin group (LD50 + Vitamin C) as shown in figure no. 6.

\subsection{Renal and Cardiac Toxicity:}

After 48 hours of the trial period, kidney histopathology and RFT (Renal Function Test) were performed to evaluate the kidney-related diseases and extent of renal damage. Table. 5 describes that Serum creatinine and Blood Urea Nitrogen (BUN) levels were significantly increased in the intoxicated rat group as compared to the control group. Here, Vitamin $\mathrm{C}$ also showed its antioxidant and protective effect on these kidney-related serum parameters.

Histopathology of a thin film of renal tissue extracted from the control group showed normal shape and space in Bowman's capsule. There was no congestion, pyknosis, karyolysis, or any necrosis in renal tubular epithelial cells. However, there was peritubular congestion, pyknosis, karyolysis, coagulative necrosis, and coagulative necrosis in renal tubular epithelial cells of the Experiment group (LD50). But, histopathology of renal tissues of the Vitamin group (LD50 + Vitamin C) showed mild congestion and coagulative necrosis as shown in figure no. 7.

After 48 hours of the trial period, histopathology of the heart was performed to evaluate the extent of heart damage. Histopathology of a thin film of cardiac tissue extracted from the control group showed normal cardiac fibers and sarcoplasm in cardiac cells. There was no fragmentation of cardiac fibers, congestion, or any necrosis in their cells. However, there was the loss of sarcoplasm and fragmentation of cardiac fibers in cardiac tissues of the Experiment group (LD50). But, histopathology of cardiac tissues of the Vitamin group (LD50 + Vitamin C) showed congestion and mild cellular degeneration as shown in figure no. 8.

These results indicate dinotefuran nephrotoxic potential. It has been reported that insecticide induced variations in kidney function markers (serum creatinine and BUN) along with histopathological changes in renal tissues are due to oxidative damage (Abdel-Daim and Abdeen 2018) because ROS increased production is said to be responsible for the reduction of GFR (Pedraza-Chaverí et al. 2000) and subsequently abnormal and deviant function of the glomerulus (Parlakpinar et al. 2005). Studies using different insecticides also supported these findings (Abouelghar et al. 2020), (Kanu et al. 2016), (Jasper et al. 2012).

Histopathology of the liver, kidney, and heart showed that dinotefuran also affects the structure of these vital organs. The only control group showed normal structure, remaining all groups including vitamin groups showed significant changes in their structure. Mild toxicity of insecticide was observed in vitamintaking rat groups. The same results were found by (Kerem et al. 2007) after acute toxicity of fenthion (an 
organophosphate insecticide). A previous study showed that co-treatment (Vitamin and insecticide) can significantly inhibit imidacloprid-induced changes in the liver of Sprague Dawley rats when they for weeks (Soujanya et al. 2013). The above discussion of biochemical parameters justifies these histopathological results.

\subsection{Bone Toxicity:}

Mean values $( \pm \mathrm{SD})$ of Weight $(\mathrm{mg})$ and Length $(\mathrm{mm})$, in different rat groups, were decreased in the experimental group as compared to the control group. As a result of which Weight / Length Index $(\mathrm{mg} / \mathrm{mm})$ in the experimental rat group was decreased (as shown in table no. 6), while Robusticity Index

$\left(\mathrm{mm} / \mathrm{mg}^{1 / 3}\right)$ in experimental rat groups was increased (as shown in the table no. 7). Again, in this case, Vitamin $\mathrm{C}$ shows its inhibitory and protective effect against the toxic effect of dinotefuran. These results explain the decreased density of bone (Monteagudo et al. 1997). There was no data available for the weight/length index and robusticity index of any rat bone against any insecticide or pesticide toxicity.

\section{Conclusion}

In light of the above discussion, we concluded that single acute exposure to dinotefuran affects the structure and functions of many vital organs (liver, kidney, heart, and bone) in mammals. It causes biochemical, hematological, histopathological, and bone-related alterations. It means that even short-term exposure to dinotefuran can be dangerous. Vitamin $\mathrm{C}$ can play a role in minimizing insecticide toxicity. However, these effects are dose-dependent.

\section{Declarations}

\section{ACKNOWLEDGEMENT}

I am thankful to the 'Four Brothers' group for providing dinotefuran. Special thanks to Miss Sana Nasir, Miss Shazma Muhammad Yar, Miss Rizwana Munir, and Miss Sana Akhter for their continuous support, encouragement, and motivation.

\section{Declaration of interests}

On the behalf of all the authors, I declare that they have no known competing financial interests or personal relationships that could have appeared to influence the work reported in this paper.

\section{Data Availability}

Raw data is available on request

\section{Consent to participate}

A the authors gave full consent to participate 


\section{Consent to Publish}

All the authors gave consent to publish this data

Plant Reproductively

Not applicable

\section{Clinical trial registration}

Not applicable

\section{Author contribution}

Dr Rahat Naseer Conceptualize and write lay out

Mr.Muhammad Ahmad Conduct lab trials

Dr.Mnnaza Raza Guide and perform analysis proof read manuscript

Dr Muhammad Shahbaz statistical design

Dr. Sehrish faryal helped and performed animal trials

Dr Muddassir manuscript writing

All the authors declare that data used in this manuscript were generated in-house and no paper mill was used.

\section{Funding}

Only departmental sources used

\section{Ethical clearance}

The research got approval from independent ethical committee of university

On behalf of all the authors

Dr. Rahat Naseer

Author /Corresponding author

\section{References}

1. Abdel-Daim MM, Abdeen A (2018) Protective effects of rosuvastatin and vitamin E against fipronilmediated oxidative damage and apoptosis in rat liver and kidney. Food Chem Toxicol 114:69-77 
2. Abouelghar GE, El-Bermawy ZA, Salman HM (2020) Oxidative stress, hematological and biochemical alterations induced by sub-acute exposure to fipronil $(\mathrm{COACH} \otimes)$ in albino mice and ameliorative effect of selenium plus vitamin E. Environ Sci Pollut R 27(8):7886-7900

3. Ambali S, Akanbi D, Igbokwe N, Shittu M, Kawu M, Ayo J (2007) Evaluation of subchronic chlorpyrifos poisoning on hematological and serum biochemical changes in mice and protective effect of vitamin C. Toxicol Sci 32(2):111-120

4. Ambali SF, Onukak C, Idris SB, Yaqub LS, Shittu Mu, Aliyu H, Kawu MU (2010) Vitamin C attenuates short-term hematological and biochemical alterations induced by acute chlorpyrifos exposure in Wistar rats. J Med Med Sci 1(10):465-477

5. Babu E, Gopalakrishnan V, Sriganth INP, Gopalakrishnan R, Sakthisekaran D (1995) Cisplatin induced nephrotoxicity and the modulating effect of glutathione ester. Mol Cell Biochem 144(1):7-11

6. Badawy MH, Ahmed NS, Attia AM (2018) Sub-acute oral toxicity of imidacloprid and fipronil pesticide mixture in male albino rats; biochemical and reproductive toxicity evaluation. J Mater Environ Sci 9:2431-2437

7. Badgujar PC, Chandratre GA, Pawar NN, Telang A, Kurade N (2016) Fipronil induced oxidative stress involves alterations in SOD 1 and catalase gene expression in male mice liver: Protection by vitamins E and C. Environ Toxicol 31(9):1147-1158

8. Bao H, Liu S, Gu J, Wang X, Liang X, Liu Z (2009) Sublethal effects of four insecticides on the reproduction and wing formation of brown planthopper, Nilaparvata lugens. Pest Manag Sci 65(2):170-174

9. Bass C, Puinean AM, Andrews M, Cutler P, Daniels M, Elias J, Paul VL, Crossthwaite AJ, Denholm I, Field LM (2011) Mutation of a nicotinic acetylcholine receptor $\beta$ subunit is associated with resistance to neonicotinoid insecticides in the aphid Myzus persicae. Bmc Neurosci 12(1):51

10. Bassini-Cameron A, Sweet E, Bottino A, Bittar C, Veiga C, Cameron L-C (2007) Effect of caffeine supplementation on haematological and biochemical variables in elite soccer players under physical stress conditions. Br J Sports Med 41(8):523-530

11. Celik I, Suzek H (2008) The hematological effects of methyl parathion in rats. J Hazard Mater 153(3):1117-1121

12. Chakroun S, Ezzi L, Grissa I, Kerkeni E, Neffati F, Bhouri R, Najjar MF, Hassine M, Mehdi M, Haouas Z (2016) Hematological, biochemical, and toxicopathic effects of subchronic acetamiprid toxicity in Wistar rats. Environ Sci Pollut R 23(24):25191-25199

13. Chakroun S, Grissa I, Ezzi L, Ammar O, Neffati F, Kerkeni E, Najjar MF, Haouas Z, Cheikh HB (2017) Imidacloprid enhances liver damage in Wistar rats: Biochemical, oxidative damage and histological assessment. J Coas Life Med 5(12):540-546

14. Chatterjee S, Basak P, Chaklader M, Das P, Pereira JA, Chaudhuri S, Law S (2014) Pesticide induced alterations in marrow physiology and depletion of stem and stromal progenitor population: an experimental model to study the toxic effects of pesticide. Environ Toxicol 29(1):84-97 
15. Chen Z, Yao X, Dong F, Duan H, Shao X, Chen X, Yang T, Wang G, Zheng Y (2019) Ecological toxicity reduction of dinotefuran to honeybee: New perspective from an enantiomeric level. Environ Int 130:104854

16. Chensheng L, Warchol KM, Callahan RA (2014) Sub-lethal exposure to neonicotinoids impaired honey bees winterization before proceeding to colony collapse disorder. Bull Insectology. 67(1): 125130

17. Codling G, Al Naggar Y, Giesy JP, Robertson AJ (2016) Concentrations of neonicotinoid insecticides in honey, pollen and honey bees (Apis mellifera L.) in central Saskatchewan. Canada Chemosphere $144: 2321-2328$

18. Corbel V, Duchon S, Zaim M, Hougard J-M (2004) Dinotefuran: a potential neonicotinoid insecticide against resistant mosquitoes. J Med Entomol 41(4):712-717

19. Cui L, Zhou Q-f, Liao C-y, Fu J-j, Jiang G-b (2009) Studies on the toxicological effects of PFOA and PFOS on rats using histological observation and chemical analysis. Arch Environ Con Tox 56(2):338

20. de Oliveira PR, Anholeto LA, Bechara GH, Mathias MIC (2017) Dinotefuran-induced morphophysiological changes in semi-engorged females Rhipicephalus sanguineus Latreille, 1806 (Acari: Ixodidae) ticks: Ultra-structural evaluation. Acta Trop 166:139-154

21. de Oliveira PR, Pizano MA, Remédio RN, Bechara GH, de Abreu RMM, Mathias MIC (2015) Potential of the chemical dinotefuran in the control of Rhipicephalus sanguineus (Latreille, 1806)(Acari: Ixodidae) semi-engorged female ticks. Exp Parasitol 155:82-88

22. Elbert A, Haas M, Springer B, Thielert W, Nauen R (2008) Applied aspects of neonicotinoid uses in crop protection. Pest Manag Sci 64(11):1099-1105

23. Enan E, EE E (1983) Comparative biochemical effects of three aliphatic organophosphorus insecticides on white rats

24. Ghazi S, Habibian M, Moeini M, Abdolmohammadi A (2012) Effects of different levels of organic and inorganic chromium on growth performance and immunocompetence of broilers under heat stress. Biol Trace Elem Res 146(3):309-317

25. Halm M-P, Rortais A, Arnold G, Taséi J, Rault S (2006) New risk assessment approach for systemic insecticides: the case of honey bees and imidacloprid (Gaucho). Environ Sci Technol 40(7):24482454

26. Hem L, El-Aty AA, Park J-H, Shim J-H (2012) Determination of dinotefuran in pepper using liquid chromatography: contribution to safety evaluation. J Korean Soc Appl Biol Chem 55(6):765-768

27. Hemingway J, Ranson H (2000) Insecticide resistance in insect vectors of human disease. Annu Rev Entomol 45(1):371-391

28. Honda H, Tomizawa M, Casida JE (2006) Insect nicotinic acetylcholine receptors: neonicotinoid binding site specificity is usually but not always conserved with varied substituents and species. $\mathrm{J}$ Agric Food Chem 54(9):3365-3371

29. Iqbal K, Khan A, Khattak M (2004) Biological significance of ascorbic acid (vitamin C) in human health-a review. Pakistan J Nutr 3(1):5-13 
30. Jadon A, Bhadauria M, Shukla S (2007) Protective effect of Terminalia belerica Roxb. and gallic acid against carbon tetrachloride induced damage in albino rats. J Ethnopharmacol 109(2):214-218

31. Jarvik GP, Tsai NT, McKinstry LA, Wani R, Brophy VH, Richter RJ, Schellenberg GD, Heagerty PJ, Hatsukami TS, Furlong CE (2002) Vitamin C and E intake is associated with increased paraoxonase activity. Arterioscler Thromb Vasc Biol 22(8):1329-1333

32. Jasper R, Locatelli GO, Pilati C, Locatelli C (2012) Evaluation of biochemical, hematological and oxidative parameters in mice exposed to the herbicide glyphosate-Roundup ${ }^{\circledR}$. Interdiscip Toxicol 5(3):133-140

33. Jeschke P, Nauen R, Schindler M, Elbert A (2010) Overview of the status and global strategy for neonicotinoids. J Agric Food chem 59(7):2897-2908

34. Kanbur M, Atalay O, Ica A, Eraslan G, Cam Y (2008) The curative and antioxidative efficiency of doramectin and doramectin + vitamin AD3E treatment on Psoroptes cuniculi infestation in rabbits. Res Vet Sci 85(2):291-293

35. Kanu KC, ljioma SN, Atiata O (2016) Haematological, biochemical and antioxidant changes in Wistar rats exposed to dichlorvos based insecticide formulation used in Southeast Nigeria. Toxics 4(4):28

36. Karmakar R, Bhattacharya R, Chatterjee M (2000) Biochemical, haematological and histopathological study in relation to time-related cadmium-induced hepatotoxicity in mice. Biometals 13(3):231-239

37. Kataria SK, Chhillar AK, Kumar A, Tomar M, Malik V (2016) Cytogenetic and hematological alterations induced by acute oral exposure of imidacloprid in female mice. Drug Chem Toxicol 39(1):59-65

38. Kerem M, Bedirli N, GürbüZ N, Ekinci O, Bedirli A, Akkaya T, Şakrak Ö, PAŞAOĞLU H (2007) Effects of acute fenthion toxicity on liver and kidney function and histology in rats. Turk J Med Sci 37(5):281288

39. Kiriyama K, Nishimura K (2002) Structural effects of dinotefuran and analogues in insecticidal and neural activities. Pest Manag Sci 58(7):669-676

40. Kobashi K, Harada T, Adachi Y, Mori M, Ihara M, Hayasaka D (2017) Comparative ecotoxicity of imidacloprid and dinotefuran to aquatic insects in rice mesocosms. Ecotox Environ Safe 138:122129

41. KOCABAĞLI N (2001) The effect of dietary phytase supplementation at different levels on tibial bone characteristics and strength in broilers. Turk J Vet Anim Sci 25(5):797-802

42. Kurwadkar ST, Dewinne D, Wheat R, McGahan DG, Mitchell FL (2013) Time dependent sorption behavior of dinotefuran, imidacloprid and thiamethoxam. J Environ Sci Heal B 48(4):237-242

43. Lal R, Arora M, Sharma A (2011) Acrylamide caused hematotoxicity on mus musculus through gavage. Indian J Fundam Appl Life Sci 1:330-334

44. Laurence D, Bennett P, Brown M (1987) Clinical Pharmacology, 8th(ed.). Churchill-Livingstone. In: London 
45. Laurino D, Porporato M, Patetta A, Manino A (2011) Toxicity of neonicotinoid insecticides to honey bees: laboratory tests. Bull Insectol 64(1):107-113

46. Liu T, Chen D, Li Y, Wang X, Wang F (2018a) Enantioselective bioaccumulation and toxicity of the neonicotinoid insecticide dinotefuran in earthworms (Eisenia fetida). J Agric Food Chem 66(17):4531-4540

47. Liu T, Wang X, Xu J, You X, Chen D, Wang F, Li Y (2017) Biochemical and genetic toxicity of dinotefuran on earthworms (Eisenia fetida). Chemosphere 176:156-164

48. Liu T, Zhang X, Wang X, Chen D, Li Y, Wang F (2018b) Comparative toxicity and bioaccumulation of two dinotefuran metabolites, UF and DN, in earthworms (Eisenia fetida). Environ Pollut 234:988-996

49. Maienfisch P, Brandl F, Kobel W, Rindlisbacher A, Senn R (1999) CGA 293'343: A novel, broadspectrum neonicotinoid insecticide. In: Nicotinoid insecticides and the nicotinic acetylcholine receptor. Springer, pp 177-209

50. Moid N, Desai KR, Korat VP, Shah IK, Highland HN, George LB (2014) Hemato-biochemical effects of technical grade deltamethrin in Swiss albino male mice, Mus musculus. Int J Pharm Sci Health Care 2(4):54-66

51. Monteagudo M, Hernandez E, Seco C, Gonzalez-Riola J, Revilla M, Villa L, Rico H (1997) Comparison of the bone robusticity index and bone weight/bone length index with the results of bone densitometry and bone histomorphometry in experimental studies. Cells Tissues Organs 160(3):195-199

52. Morrissey CA, Mineau P, Devries JH, Sanchez-Bayo F, Liess M, Cavallaro MC, Liber K (2015) Neonicotinoid contamination of global surface waters and associated risk to aquatic invertebrates: a review. Environ Int 74:291-303

53. Murphy MP (2009) How mitochondria produce reactive oxygen species. Biochem J 417(1):1-13

54. Nair RR, Abraham MJ, Lalithakunjamma C, Nair N, Aravindakshan C (2010) Hematological and biochemical profile in sub lethal toxicity of cypermethrin in rats. Int J Biol Med Res 1(4):211-214

55. Nyman A-M, Hintermeister A, Schirmer K, Ashauer R (2013) The insecticide imidacloprid causes mortality of the freshwater amphipod Gammarus pulex by interfering with feeding behavior. PloS one 8(5):e62472

56. Parlakpinar H, Tasdemir S, Polat A, Bay-Karabulut A, Vardi N, Ucar M, Acet A (2005) Protective role of caffeic acid phenethyl ester (cape) on gentamicin-induced acute renal toxicity in rats. Toxicology 207(2):169-177

57. Patil SB, Kodliwadmath M, Kodliwadmath SM (2008) Correlation between lipid peroxidation and nonenzymatic antioxidants in pregnancy induced hypertension. Indian J Clin Biochem 23(1):45-48

58. Pedraza-Chaverrí J, Maldonado PD, Medina-Campos ON, Olivares-Corichi IM, de los Ángeles Granados-Silvestre Ma, Hernández-Pando R, Ibarra-Rubio MaE (2000) Garlic ameliorates gentamicin nephrotoxicity: relation to antioxidant enzymes. Free Radic Biol Med. 29(7): 602-611

59. Rahman MM, El-Aty AA, Choi J-H, Kim S-W, Shin SC, Shim J-H (2015) Consequences of the matrix effect on recovery of dinotefuran and its metabolites in green tea during tandem mass spectrometry 
analysis. Food Chem 168:445-453

60. Sathiavelu J, Senapathy GJ, Devaraj R, Namasivayam N (2009) Hepatoprotective effect of chrysin on prooxidant-antioxidant status during ethanol-induced toxicity in female albino rats. J Pharm 61(6):809-817

61. Scandalios J (2005) Oxidative stress: molecular perception and transduction of signals triggering antioxidant gene defenses. Braz J Med Biol Res 38(7):995-1014

62. Seedor JG, Quartuccio HA, Thompson DD (1991) The bisphosphonate alendronate (MK-217) inhibits bone loss due to ovariectomy in rats. J Bone Miner Res 6(4):339-346

63. Sheets L (1994) An subchronic dietary neurotoxicity screening study with Technical Grade imidacloprid (NTN 33893) in Fischer-344 rats. Miles Inc (Mobay) Study.(106356): 51950-50471

64. Sheets LP (2010) Imidacloprid: a neonicotinoid insecticide. In: Hayes' handbook of pesticide toxicology. Elsevier, pp 2055-2064

65. Shi X, Jiang L, Wang H, Qiao K, Wang D, Wang K (2011) Toxicities and sublethal effects of seven neonicotinoid insecticides on survival, growth and reproduction of imidacloprid-resistant cotton aphid, Aphis gossypii. Pest Manag Sci 67(12):1528-1533

66. Soujanya S, Lakshman M, Kumar AA, Reddy AG (2013) Evaluation of the protective role of vitamin C in imidacloprid-induced hepatotoxicity in male Albino rats. J Nat Sci Biol Medicine 4(1):63

67. Subramanian M (2019) Toxicology: Principles and Methods. MJP Publisher

68. Swelam E, Abdallah I, Mossa A (2017) Ameliorating effect of zinc against oxidative stress and lipid peroxidation induced by fipronil in male rats. J Pharmacol Toxicol 12(1):24-32

69. Takada T, Yoneda N, Hirano T, Yanai S, Yamamoto A, Mantani Y, Yokoyama T, Kitagawa H, Tabuchi Y, Hoshi N (2018) Verification of the causal relationship between subchronic exposures to dinotefuran and depression-related phenotype in juvenile mice. J Vet Med Sci 80(4):720-724

70. Tomizawa M, Casida JE (2005) Neonicotinoid insecticide toxicology: mechanisms of selective action. Annu Rev Pharmacol Toxicol 45:247-268

71. Ündeğer Ü, Başaran N (2005) Effects of pesticides on human peripheral lymphocytes in vitro: induction of DNA damage. Arch Toxicol 79(3):169-176

72. Uzun FG, Kalender Y (2013) Chlorpyrifos induced hepatotoxic and hematologic changes in rats: the role of quercetin and catechin. Food Chemical Toxicol 55:549-556

73. Uzunhisarcikli M, Kalender Y (2011) Protective effects of vitamins C and E against hepatotoxicity induced by methyl parathion in rats. Ecotoxicol Environ Saf 74(7):2112-2118

74. Vohra P, Khera KS, Sangha GK (2014) Physiological, biochemical and histological alterations induced by administration of imidacloprid in female albino rats. Pestic Biochem Phys 110:50-56

75. Wada TYKYN (2012) Influence of dinotefuran and clothianidin on a bee colony. Jpn J Clin Ecol 21(1)

76. Wakita T, Kinoshita K, Yamada E, Yasui N, Kawahara N, Naoi A, Nakaya M, Ebihara K, Matsuno H, Kodaka K (2003) The discovery of dinotefuran: a novel neonicotinoid. Pest Manag Scie 59(9):10161022 
77. Wang Y, Han Y, Xie Y, Xu P, Li W (2018) The metabolism distribution and effect of dinotefuran in Chinese lizards (Eremias argus). Chemosphere 211:591-599

78. Watanabe E, Baba K, Miyake S (2011) Analytical evaluation of enzyme-linked immunosorbent assay for neonicotinoid dinotefuran for potential application to quick and simple screening method in rice samples. Talanta 84(4):1107-1111

79. Watanabe E, Kobara Y, Miyake S (2012) Validation of a commercial ELISA for the analysis of the insecticide dinotefuran in a variety of analytically challenging vegetables. Food Addit Contam $A$ 29(7):1067-1073

80. Xu H-Q, Liu Y-Y, Zhu G-D, Xue M (2014) Comparison of toxicity and safety evaluation of 16 kinds of pesticides on Trichogramma ostriniae and Encarsia formosa. J Environ Entomol 36:959-964

81. Yavuz T, Delibas N, Yildirim B, Altuntas I, Candır O, Cora A, Karaman N, Ibrisim E, Kutsal A (2004) Vascular wall damage in rats induced by methidathion and ameliorating effect of vitamins $E$ and $C$. Arch Toxicol 78(11):655-659

82. Yoneda N, Takada T, Hirano T, Yanai S, Yamamoto A, Mantani Y, Yokoyama T, Kitagawa H, Tabuchi Y, Hoshi N (2018) Peripubertal exposure to the neonicotinoid pesticide dinotefuran affects dopaminergic neurons and causes hyperactivity in male mice. J Vet Med Sci 80(4):634-637

83. Zeinali M, Meybodi NT, Rezaee SA, Rafatpanah H, Hosseinzadeh H (2018) Protective effects of chrysin on sub-acute diazinon-induced biochemical, hematological, histopathological alterations, and genotoxicity indices in male BALB/c mice. Drug Chem Toxicol 41(3):270-280

\section{Tables}

Table No. 1: Mean ( \pm SD) values of WBCs and its types in different rat groups. Control Group = Rat group fed with only normal diet (no exposure of pesticide or vitamin), E-Group = Rat group fed with $L_{50}, \mathrm{~V}$ Group $=$ Rat group fed with $L D_{50}+$ Vit $C$.

\begin{tabular}{|llll|}
\hline Parameter & Control Group & E-Group & V-Group \\
\hline WBC $\left(10^{\wedge} 9 / L\right)$ & $8.62^{\mathrm{a}} \pm 0.67$ & $4.62^{\mathrm{b}} \pm 0.94$ & $5.08^{\mathrm{b}} \pm 1.04$ \\
\hline LYM $\left(10^{\wedge} 9 / \mathrm{L}\right)$ & $6.93^{\mathrm{a}} \pm 0.01$ & $8.97^{\mathrm{b}} \pm 0.59$ & $8.33^{\mathrm{c}} \pm 0.21$ \\
\hline MID $\left(10^{\wedge} 9 / \mathrm{L}\right)$ & $0.68^{\mathrm{a}} \pm 0.18$ & $0.26^{\mathrm{b}} \pm 0.02$ & $0.36^{\mathrm{b}} \pm 0.06$ \\
\hline GRA $\left(10^{\wedge} 9 / \mathrm{L}\right)$ & $0.55^{\mathrm{a}} \pm 0.03$ & $0.29^{\mathrm{b}} \pm 0.05$ & $0.31^{\mathrm{b}} \pm 0.04$ \\
\hline
\end{tabular}

Mean values with different subscripts differ significantly $(p \leq 0.05)$

Table No. 2: Mean ( \pm SD) values of RBCs and related parameters in different rat groups. Control Group = Rat group fed with only normal diet (no exposure of pesticide or vitamin), E-Group = Rat group fed with $\mathrm{LD}_{50}, \mathrm{~V}$-Group $=$ Rat group fed with $\mathrm{LD}_{50}+$ Vit $\mathrm{C}$. 


\begin{tabular}{|llll|}
\hline Parameter & C-Group & E-Group & V-Group \\
\hline RBC $\left(10^{\wedge} 12 / \mathrm{L}\right)$ & $7.63^{\mathrm{a}} \pm 0.74$ & $5.18^{\mathrm{b}} \pm 0.64$ & $6.13^{\mathrm{c}} \pm 0.41$ \\
\hline HGB $(\mathrm{g} / \mathrm{dl})$ & $14.70^{\mathrm{a}} \pm 0.68$ & $10.70^{\mathrm{b}} \pm 0.45$ & $11.21^{\mathrm{b}} \pm 1.09$ \\
\hline HCT \% & $40.84^{\mathrm{a}} \pm 2.3$ & $30.29^{\mathrm{b}} \pm 1.52$ & $32.71^{\mathrm{c}} \pm 1.05$ \\
\hline MCV (fl) & $52.14^{\mathrm{a}} \pm 2.62$ & $58.00^{\mathrm{b}} \pm 2.28$ & $57.54^{\mathrm{b}} \pm 1.94$ \\
\hline MCH (pg) & $17.30^{\mathrm{a}} \pm 1.46$ & $20.60^{\mathrm{b}} \pm 0.8$ & $19.83^{\mathrm{b}} \pm 1.17$ \\
\hline MCHC (g/dL) & $34.13^{\mathrm{a}} \pm 1.93$ & $35.20^{\mathrm{a}} \pm 0.71$ & $35.13^{\mathrm{a}} \pm 0.7$ \\
\hline RDWc \% & $21.55^{\mathrm{a}} \pm 2.06$ & $15.30^{\mathrm{b}} \pm 1.22$ & $16.67^{\mathrm{b}} \pm 2.77$ \\
\hline
\end{tabular}

Mean values with different subscripts differ significantly $(p \leq 0.05)$

Table No. 3: Mean ( \pm SD) values of Platelets and related parameters in different rat groups. Control Group $=$ Rat group fed with only normal diet (no exposure of pesticide or vitamin), E-Group $=$ Rat group fed with $L D_{50}, \mathrm{~V}-$ Group $=$ Rat group fed with $\mathrm{LD}_{50}+$ Vit $\mathrm{C}$.

\begin{tabular}{|llll|}
\hline Parameter & Control Group & E-Group & V-Group \\
\hline PLT $\left(10^{\wedge} 9 / \mathrm{L}\right)$ & $554^{\mathrm{a}} \pm 5.7$ & $459^{\mathrm{b}} \pm 3.16$ & $507^{\mathrm{c}} \pm 5.96$ \\
\hline PCT \% & $0.52^{\mathrm{a}} \pm 0.03$ & $0.27^{\mathrm{b}} \pm 0.04$ & $0.30^{\mathrm{b}} \pm 0.03$ \\
\hline MPV (fl) & $5.80^{\mathrm{a}} \pm 0.68$ & $6.60^{\mathrm{a}} \pm 1.09$ & $6.40^{\mathrm{a}} \pm 0.11$ \\
\hline PDWc $\left(10^{\wedge} 9 / \mathrm{L}\right)$ & $33.20^{\mathrm{a}} \pm 1.29$ & $35.20^{\mathrm{b}} \pm 0.79$ & $34.50^{\mathrm{ab}} \pm 0.84$ \\
\hline PLCR \% & $9.03^{\mathrm{a}} \pm 0.44$ & $21.17^{\mathrm{b}} \pm 0.7$ & $20.58^{\mathrm{b}} \pm 0.96$ \\
\hline
\end{tabular}

Mean values with different subscripts differ significantly $(p \leq 0.05)$

Table No. 4: Mean ( \pm SD) values of Liver Function Test (LFT) in different rat groups. Control Group = Rat group fed with only normal diet (no exposure of pesticide or vitamin), E-Group = Rat group fed with $L_{50}$, V-Group = Rat group fed with $L D_{50}+$ Vit $C$. 


\begin{tabular}{|llll|}
\hline Parameter & Control Group & E-Group & V-Group \\
\hline ALP (U/L) & $155^{\mathrm{a}} \pm 4.00$ & $316.8^{\mathrm{b}} \pm 1.79$ & $275.8^{\mathrm{c}} \pm 2.59$ \\
\hline ALT (U/L) & $21.4^{\mathrm{a}} \pm 2.51$ & $47.8^{\mathrm{b}} \pm 3.11$ & $43.6^{\mathrm{c}} \pm 3.05$ \\
\hline AST (U/L) & $107.4^{\mathrm{a}} \pm 2.70$ & $167.2^{\mathrm{b}} \pm 2.17$ & $153.8^{\mathrm{c}} \pm 3.27$ \\
\hline Bilirubin Total $(\mathrm{mg} / \mathrm{dL})$ & $0.42^{\mathrm{a}} \pm 0.08$ & $1.88^{\mathrm{b}} \pm 0.18$ & $1.44^{\mathrm{c}} \pm 0.05$ \\
\hline
\end{tabular}

Mean values with different subscripts differ significantly $(p \leq 0.05)$

Table No. 5: Mean ( \pm SD) values of Renal Function Test (RFT) in different rat groups. Control Group = Rat group fed with only normal diet (no exposure of pesticide or vitamin), E-Group = Rat group fed with $L D_{50}$, V-Group = Rat group fed with $L D_{50}+$ Vit C.

\begin{tabular}{|llll|}
\hline Parameter & Control Group & E-Group & V-Group \\
\hline Serum Creatinine $(\mathrm{mg} / \mathrm{dL})$ & $0.34^{\mathrm{a}} \pm 0.03$ & $1.11^{\mathrm{b}} \pm 0.03$ & $0.98^{\mathrm{c}} \pm 0.04$ \\
\hline BUN $(\mathrm{mg} / \mathrm{dL})$ & $15.4^{\mathrm{a}} \pm 1.14$ & $28^{\mathrm{b}} \pm 2.74$ & $26^{\mathrm{b}} \pm 3.74$ \\
\hline
\end{tabular}

Mean values with different subscripts differ significantly $(p \leq 0.05)$

Table No. 6: Weight / Length Index ( $\mathrm{mg} / \mathrm{mm}$ ) of left tibia of different rat groups. Control Group = Rat group fed with only normal diet (no exposure of pesticide or vitamin), E-Group = Rat group fed with $L_{50}$, V-Group = Rat group fed with $L D_{50}+$ Vit $C$.

\begin{tabular}{|llll|}
\hline Parameter & Control Group & E-Group & V-Group \\
\hline W/L Index $(\mathrm{mg} / \mathrm{mm})$ & 20.63 & 16.83 & 17.13 \\
\hline
\end{tabular}

Table No. 7: Robusticity Index ( $\mathrm{mm} / \mathrm{mg}^{1 / 3}$ ) of left tibia of different rat groups. Control Group = Rat group fed with only normal diet (no exposure of pesticide or vitamin), E-Group = Rat group fed with $L_{50}, \mathrm{~V}$ Group $=$ Rat group fed with $L_{50}+$ Vit $C$.

\begin{tabular}{|llll|}
\hline Parameter & Control Group & E-Group & V-Group \\
\hline Robusticity Index $\left(\mathrm{mm} / \mathrm{mg}^{1 / 3}\right)$ & 2.229 & 2.295 & 2.285 \\
\hline
\end{tabular}

\section{Figures}




\section{Comparative Analysis of WBCs and its Types}

12.00

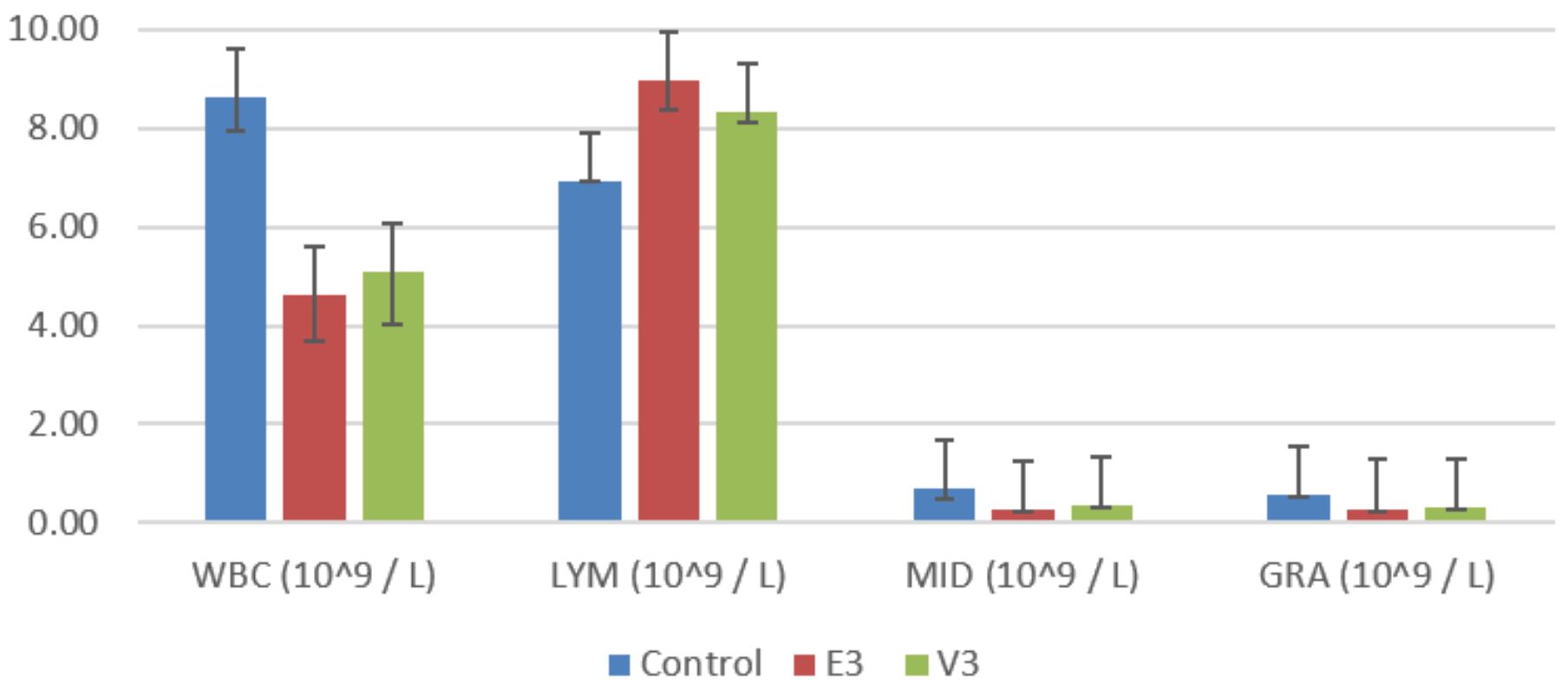

Figure 1

Comparative analysis of WBCs and its types in different rat groups. E1 = Rat group fed with LD10, E2 = Rat group fed with LD25, E3 = Rat group fed with LD50, V1 = Rat group fed with LD10 + Vit C, V2 = Rat group fed with LD25 + Vit C, V3 = Rat group fed with LD50 + Vit C. 


\section{Comparative Analysis of RBCs and Related Parameters}

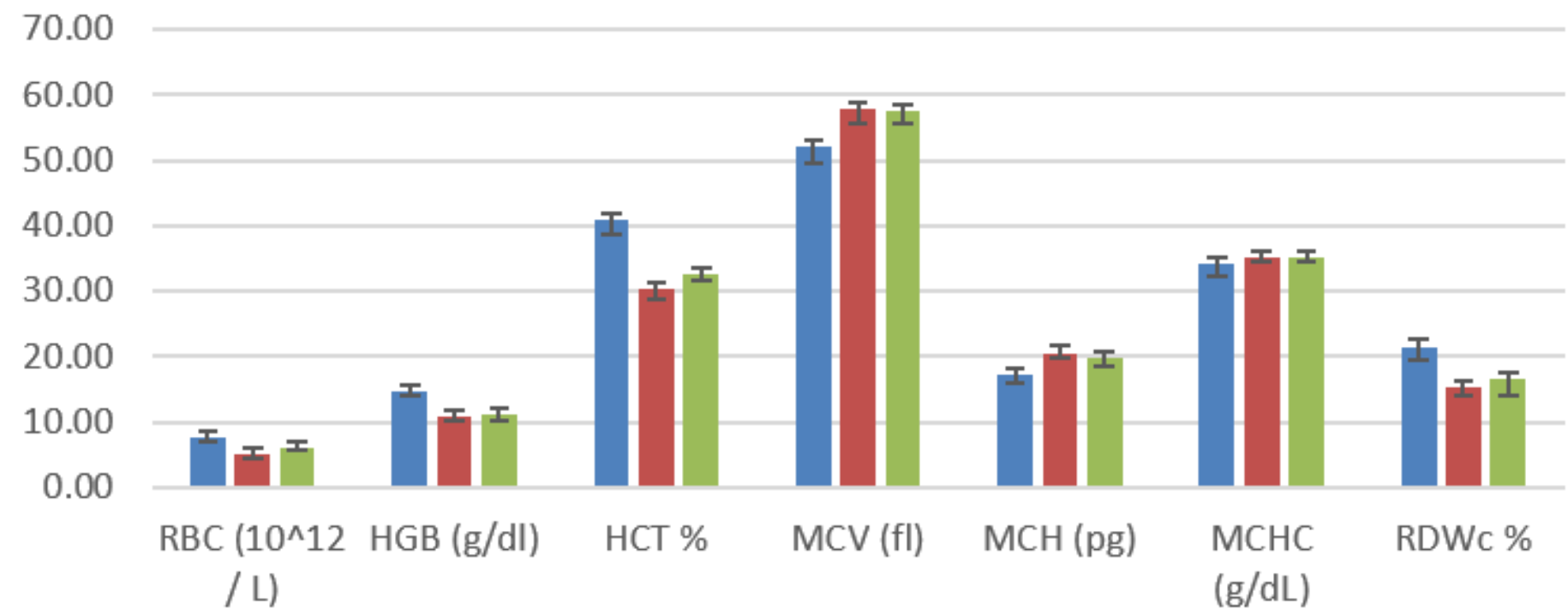

Control $\quad$ E3 $\square$ V3

\section{Figure 2}

Comparative analysis of RBCs and related parameters in different rat groups. E1 = Rat group fed with LD10, E2 = Rat group fed with LD25, E3 = Rat group fed with LD50, V1 = Rat group fed with LD10 + Vit C, V2 = Rat group fed with LD25 + Vit C, V3 = Rat group fed with LD50 + Vit C. 


\section{Comparative Analysis of Platelets and Related Parameters}

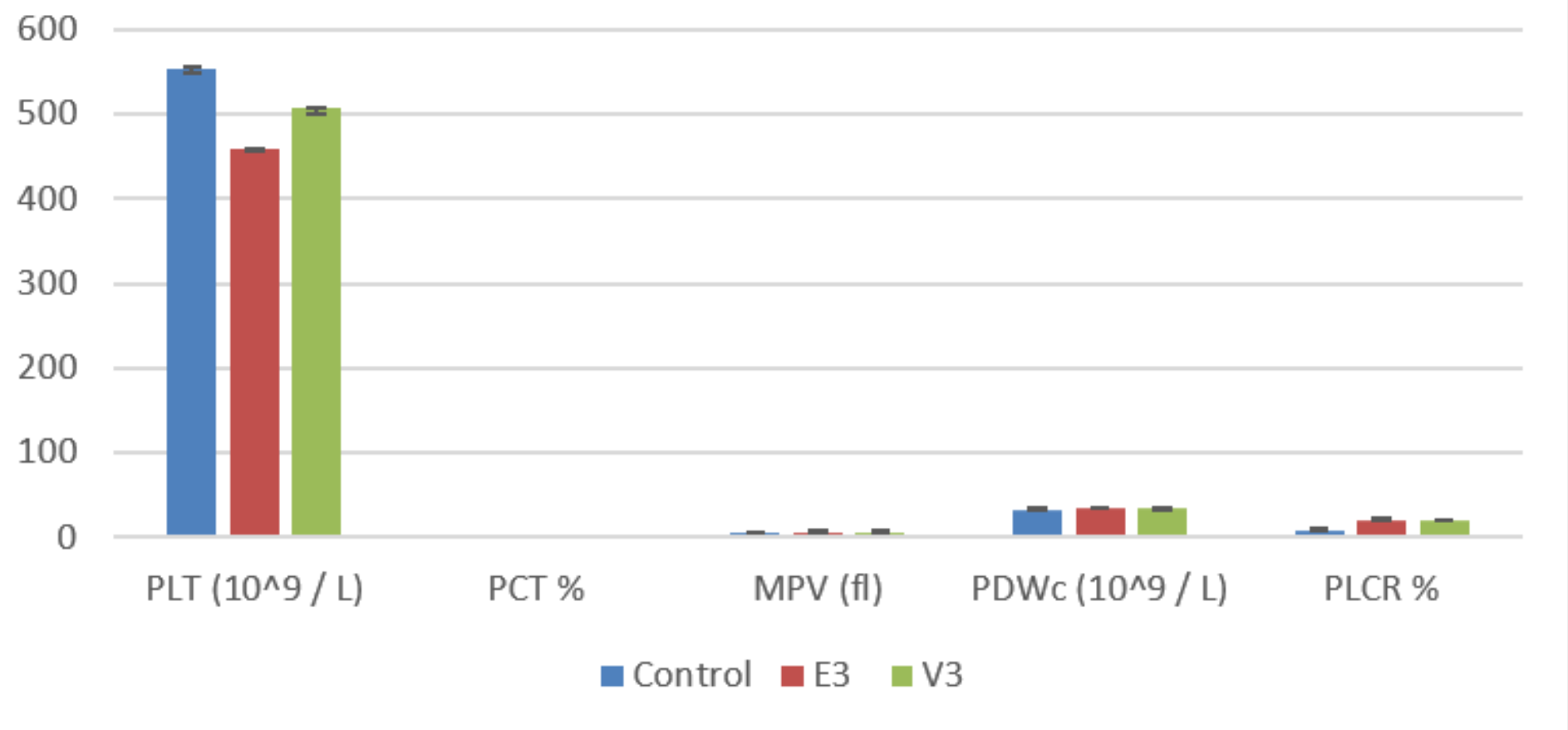

\section{Figure 3}

Comparative analysis of Platelets and related parameters in different rat groups. E1 = Rat group fed with LD10, E2 = Rat group fed with LD25, E3 = Rat group fed with LD50, V1 = Rat group fed with LD10 + Vit C, V2 = Rat group fed with LD25 + Vit C, V3 = Rat group fed with LD50 + Vit C. 


\section{Comparative Analysis of LFT in Different Rat Groups}

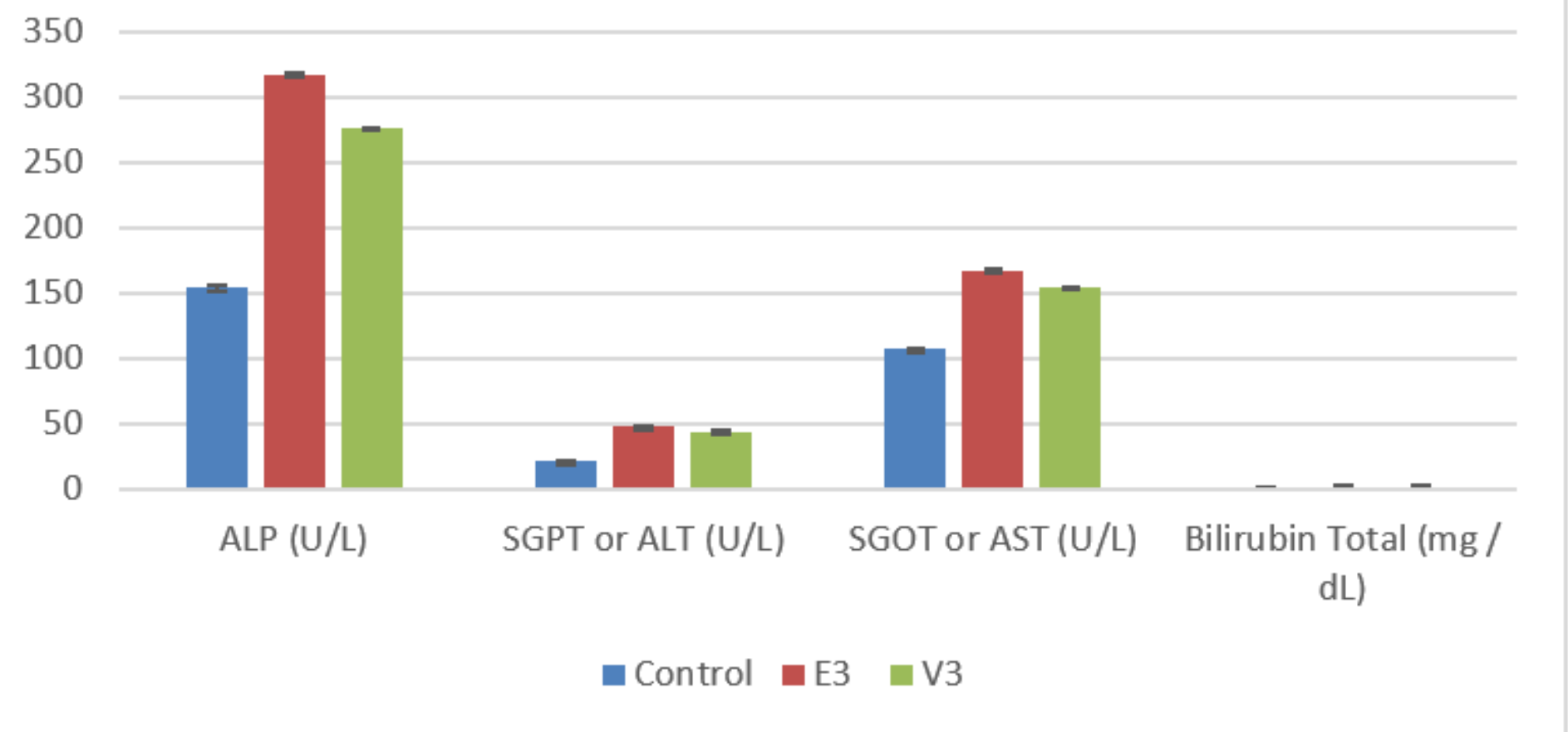

\section{Figure 4}

Comparative analysis of Liver Function Test (LFT) in different rat groups. E1 = Rat group fed with LD10, E2 = Rat group fed with LD25, E3 = Rat group fed with LD50, V1 = Rat group fed with LD10 + Vit C, V2 = Rat group fed with LD25 + Vit C, V3 = Rat group fed with LD50 + Vit C. 


\section{Comparative Analysis of RFT in Different Rat Groups}

35.00

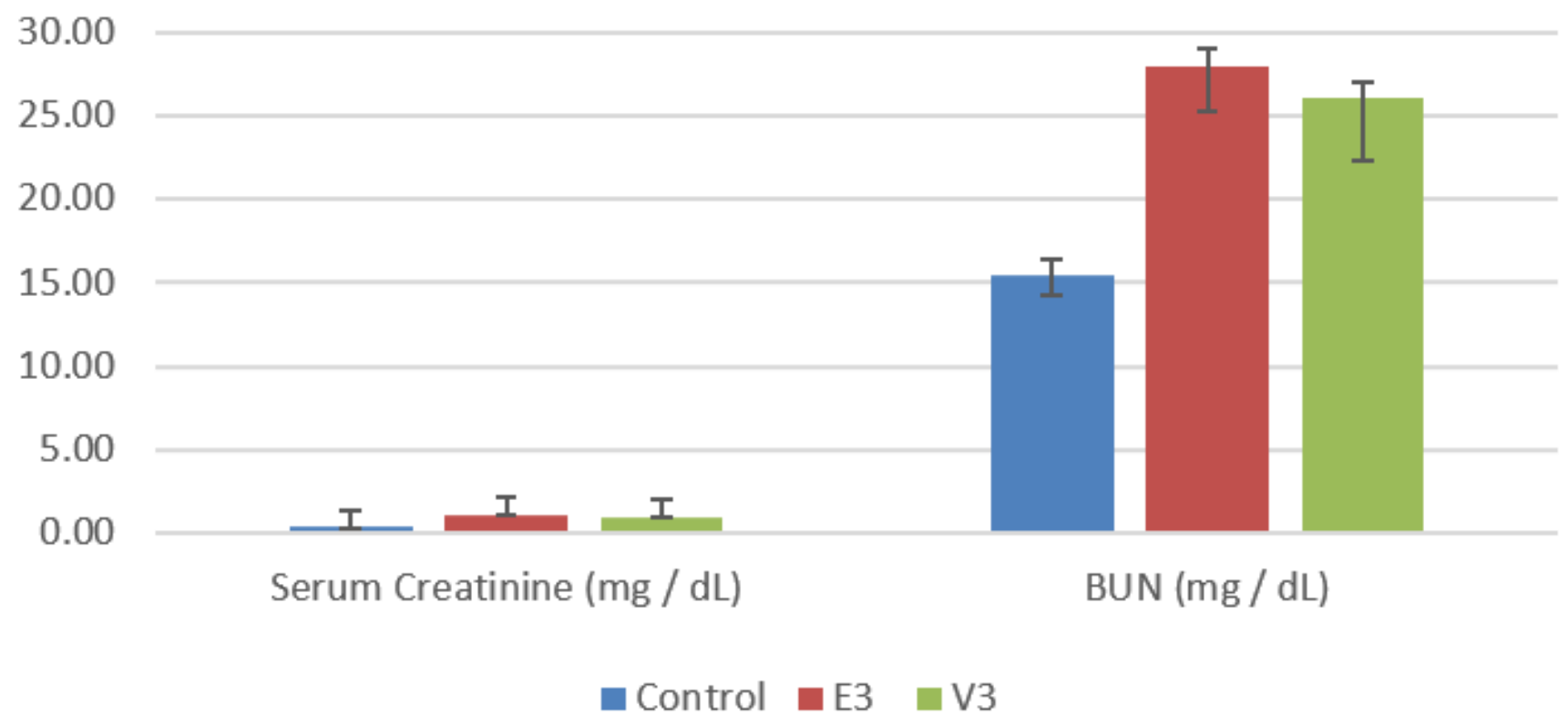

\section{Figure 5}

Comparative analysis of Renal Function Test (RFT) in different rat groups. E1 = Rat group fed with LD10, E2 = Rat group fed with LD25, E3 = Rat group fed with LD50, V1 = Rat group fed with LD10 + Vit C, V2 = Rat group fed with LD25 + Vit C, V3 = Rat group fed with LD50 + Vit C.

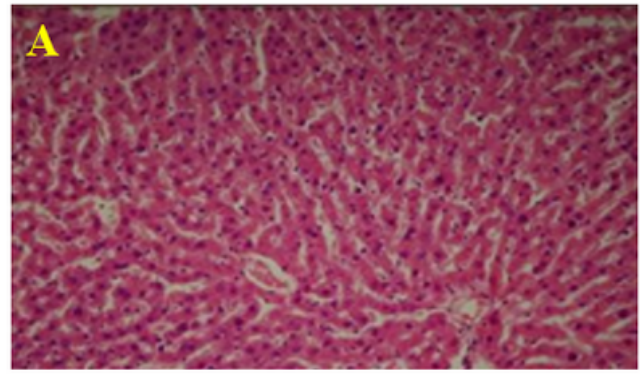

A = Normal Liver of Control (40X)

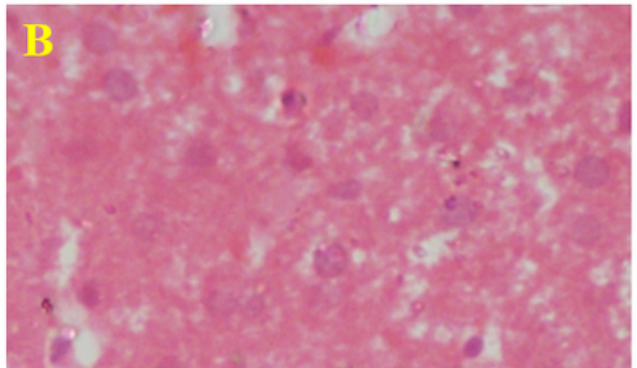

B = Liver of Experiment Group (40X)

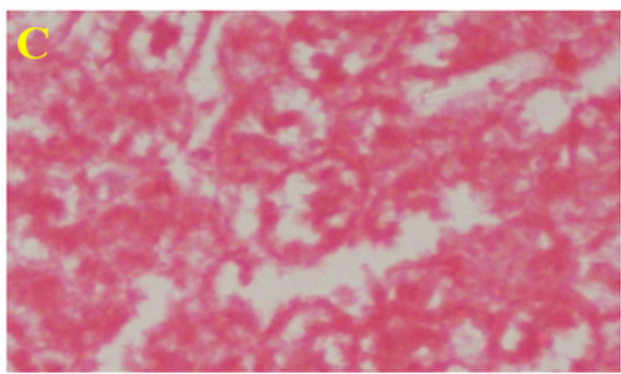

C = Liver of Vitamin Group (40X)

\section{Figure 6}

Liver Histopathology of different rat groups. 


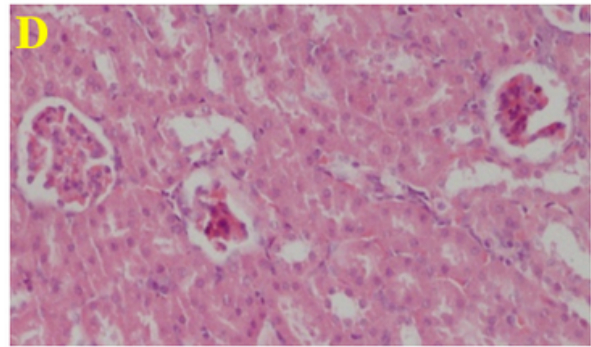

D = Normal Kidney of Control (10X)

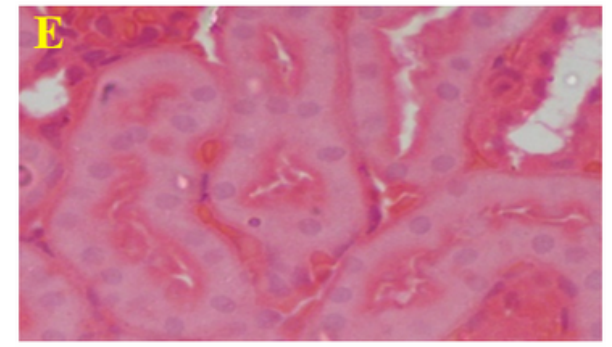

E = Kidney of Experiment Group (40X)

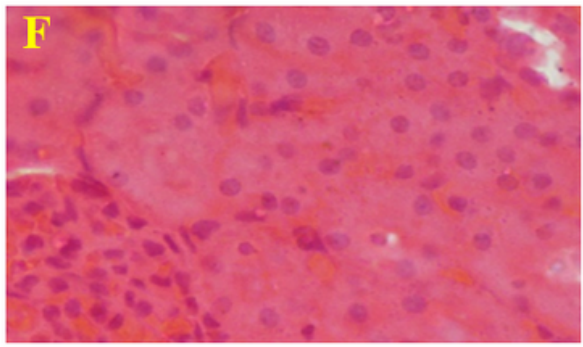

F = Kidney of Vitamin Group (40X)

\section{Figure 7}

Renal Histopathology of different rat groups.

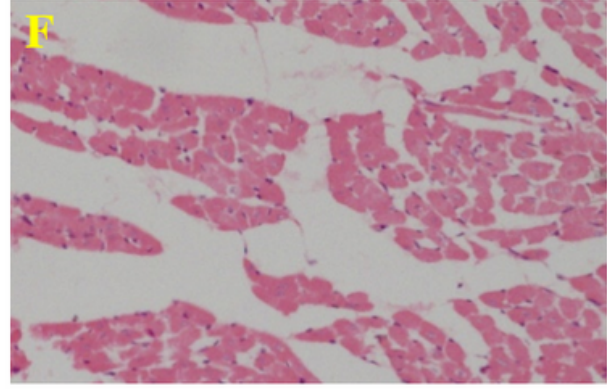

F $=$ Normal Heart of Control (10X)

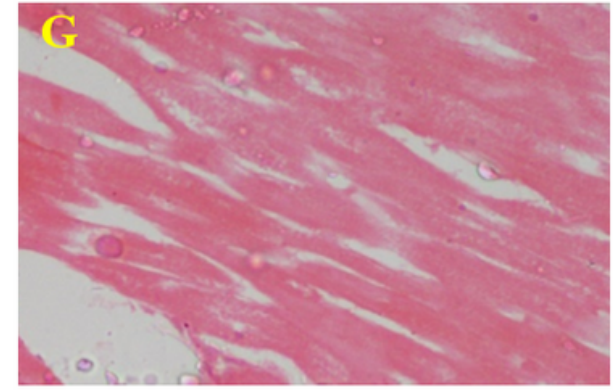

G = Heart of Experiment Group (40X)

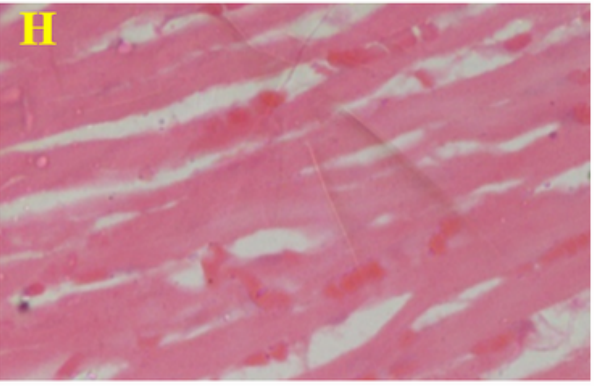

H = Heart of Vitamin Group (40X)

\section{Figure 8}

Histopathology of heart of different rat groups. 